\title{
Analisis Pengaruh Program Nasional Pemberdayaan Masyarakat Mandiri Perkotaan (PNPM MP) Terhadap Produktifitas Kerja Dan Kesejahteraan Masyarakat
}

\author{
Putu Bayu Putra Mahendra * \\ 1 Program Pascasarjana Universitas Udayana
}

\section{Abstrak}

Penelitian ini bertujuan untuk menganalisis pengaruh Bantuan Langsung Masyarakat (BLM) bidang infrastruktur dari Program Nasional Pemberdayaan Masyarakat (PNPM) Mandiri perkotaan terhadap produktivitas kerja masyarakat di Kecamatan Denpasar Utara. Untuk menganalisis pengaruh Bantuan Langsung Masyarakat (BLM) bidang infrastruktur dari Program Nasional Pemberdayaan Masyarakat (PNPM) Mandiri perkotaan terhadap kesejahteraan masyarakat melalui produktivitas kerja masyarakat di Kecamatan Denpasar Utara. Data dikumpulkan dengan kuesioner dan dianalisis dengan analisis paht. Hasil penelitian menunjukkan bahwa program PNPM Mandiri Perkotaan bidang infrastruktur berpengaruh positif terhadap Produktivitas di Kecamatan Denpasar Utara Produktivitas berpengaruh positif terhadap Kesejahteraan Masyarakat PNPM Mandiri Perdesaan di Kecamatan Denpasar Utara. Program PNPM Mandiri Perkotaan bidang infrastruktur berpengaruh positif terhadap Kesejahteraan Masyarakat PNPM Mandiri Perdesaan di Kecamatan Denpasar Utara.
\end{abstract}

\section{Kata Kunci:}

Pemberdayaan masyarakat, produktifitas, kesejahtraan msayarakat

\section{Pendahuluan}

Perubahan paradigma dalam pengelolaan dan penyelenggaraan pemerintahan dari sentralistik ke desentralistik telah memberikan nuansa baru yang sama sekali berbeda dari situasi sebelumnya. Otonomi Daerah juga dapat dimaknai sebagai hak dan wewenang daerah untuk mengatur dan mengurus kepentingan masyarakat setempat menurut kebijakan, prakarsa dan kemampuan sendiri berdasarkan aspirasi masyarakat. Otonomi Daerah telah membuka peluang dan kesempatan luas bagi daerah untuk merekonstruksikan format penyelenggaraan pemerintahan lokal yang sesuai dengan karakteristik masyarakat setempat, karena Otonomi Daerah harus dibarengi dengan basis kultural masyarakat lokal.

Sebagai daerah otonom, semua kabupaten dan Kota di Provinsi Bali memilih mengembangkan destinasi pariwisata sebagai pendapatan utamanya. Misalnya di Kota Denpasar, status Kota Denpasar sebagai pusat kebudayaan dan pariwisata di Provinsi Bali berimplikasi pada pertumbuhan perekonomian yang sangat pesat. Sesuai Peraturan Walikota Nomor 31 tahun 2014 akumulasi Pendapatan Asli daerah tahun 2013 mencapai Rp. 586,95 miliar atau 39,2 persen dari target Anggaran Pendapatan dan Belanja Daerah (APBD) tahun 2013 yaitu sebesar Rp. 1,49 triliun. Dana Perimbangan menjadi kontributor utama sebesar Rp. 666,25 miliar atau 44,6 persen dari target Anggaran Pendapatan dan Belanja Daerah (APBD) tahun 2013. Secara nominal Dana Perimbangan tahun 2013 lebih besar dibandingkan tahun 2012 yaitu sebesar Rp. 614,15 miliar (Pemerintah Kota Denpasar, 2014).

Dengan pendapatan sebesar itu, masyarakat Kota Denpasar memiliki impian hidup yang sejahtera, harmonis, dan bahagia. Sejahtera yang dimaksud adalah kesejahteraan menurut UndangUndang No 13 tahun 1998 yaitu suatu tata kehidupan dan penghidupan masyarakat baik materil maupun spiritual yang diliputi oleh rasa takut, keselamatan kesusilaan dan ketentraman lahir dan batin yang memungkinkan bagi setiap masyarakat untuk mengadakan usaha penemuan kebutuhan-kebutuhan jasmani dan sosial yang sebaik-baiknya bagi diri, keluarga serta masyarakat dengan menjunjung tinggi hak asasi serta kewajiban manusia sesuai dengan pancasila. Namun kenyataannya masih banyak terdapat masyarakat di Kota Denpasar yang belum berkategori sejahtera, bahkan masih banyak keluarga yang tergolong keluarga pra sejahtera dengan kategori keluarga miskin. Hal ini dapat dilihat dari masih banyaknya msyarakat Kota Denpasar yang belum memenuhi 5 indikator kebutuhan dasar keluarga sejahtera yaitu: kebutuhan spiritual, pangan, sandang, papan, dan kesehatan. 
Berdasarkan Keputusan Walikota Denpasar Tahun 2010 Kota Denpasar masih memiliki penduduk miskin sejumlah 11.423 orang (Pemerintah Kota Denpasar, 2010). Sebaran jumlah penduduk miskin menurut Keputusan Walikota Denpasar sampai dengan tahun 2014 masing-masing kecamatan di Kota Denpasar dapat dilihat pada Tabel 1.

Tabel 1. Jumlah Penduduk Miskin Menurut Kecamatan di Kota Denpasar Tahun 2010 s/d 2014

\begin{tabular}{ccccccc}
\hline No & Kecamatan & $\mathbf{2 0 1 0}$ & $\mathbf{2 0 1 1}$ & $\mathbf{2 0 1 2}$ & $\mathbf{2 0 1 3}$ & $\mathbf{2 0 1 4}$ \\
\hline 1 & Denpasar Utara & 4595 & 4112 & 3.585 & 3.466 & 2.991 \\
2 & Denpasar Timur & 2334 & 2096 & 1.525 & 1.316 & 1.368 \\
3 & Denpasar Selatan & 1684 & 1550 & 1.255 & 1.073 & 1.084 \\
4 & Denpasar Barat & 2810 & 2358 & 1.816 & 1.580 & 1.519 \\
\hline & Kota Denpasar & $\mathbf{1 1 . 4 2 3}$ & $\mathbf{1 0 . 1 1 6}$ & $\mathbf{8 . 1 8 1}$ & $\mathbf{7 . 4 3 5}$ & $\mathbf{6 . 9 6 2}$ \\
\hline
\end{tabular}

Berdasarkan tabel 1 Pemerintah Kota Denpasar memandang masalah kemiskinan sebagai masalah serius, terutama dengan semakin banyaknya permasalahan sosial ekonomi dan politik yang ditimbulkannya. Modernisasi dan industrialisasi di Kota Denpasar sering kali dituding sebagai pemicu, di antara beberapa pemicu yang lain, yang menyebabkan Kota Denpasar mengalami perkembangan yang sangat pesat sehingga mengundang terjadinya urbanisasi dan kemudian komunitas-komunitas kumuh atau daerah kumuh yang identik dengan kemiskinan perkotaan. Dengan melihat sisi kemiskinan di Kota Denpasar seperti masih adanya masyarakat yang menganggur, keterbelakangan dalam bidang pendidikan, dan ketidakberdayaan dalam berdaya saing kerja, maka kemiskinan di Kota Denpasar merupakan masalah yang urgen dan harus menjadi prioritas utama dalam pelaksanaan pembangunan Kota Denpasar.

Salah satu program yang sedang berkembang dan terus disempurnakan berkaitan dengan kebijakan penanggulangan kemiskinan di perkotaan yang berbasis pada konsep pemberdayaan masyarakat adalah Program Penanggulangan Kemiskinan di Perkotaan (P2KP). Kebijakan ini telah dilaksanakan sejak tahun 1999 sebagai suatu upaya pemerintah untuk membangun kemandirian masyarakat dan pemerintah daerah dalam menanggulangi masalah kemiskinan secara mandiri. (www.p2kp.org, 2014). Program ini di bawahi oleh Departemen Permukiman dan Prasarana Wilayah (Kimpraswil) selanjutnya berkembang menjadi Program Nasional Pemberdayaan Masyarakat (PNPM) Mandiri Perkotaan.

Mulai tahun 2007 Pemerintah Indonesia mencanangkan Program Nasional Pemberdayaan Masyarakat (PNPM) Mandiri yang terdiri dari PNPM Mandiri Pedesaan, PNPM Mandiri Perkotaan, serta PNPM Mandiri wilayah khusus dan desa tertinggal. PNPM Mandiri Pedesaan adalah program untuk mempercepat penanggulangan kemiskinan secara terpadu dan berkelanjutan. Pendekatan PNPM Mandiri Pedesaan merupakan pengembangan dari Program Pengembangan Kecamatan (PPK), yang selama ini dinilai berhasil. Beberapa keberhasilan PPK adalah berupa penyediaan lapangan kerja dan pendapatan bagi kelompok rakyat miskin, efisiensi dan efektivitas kegiatan, serta berhasil menumbuhkan kebersamaan dan partisipasi masyarakat. Visi PNPM Mandiri Pedesaan adalah tercapainya kesejahteraan dan kemandirian masyarakat miskin pedesaan. Kesejahteraan berarti terpenuhinya kebutuhan dasar masyarakat. Kemandirian berarti mampu mengorganisir diri untuk memobilisasi sumber daya yang ada di lingkungannya, mampu mengakses sumber daya di luar lingkungannya, serta mengelola sumber daya tersebut untuk mengatasi masalah kemiskinan.

Misi PNPM Mandiri Pedesaan adalah: (1) peningkatankapasitas masyarakat dan kelembagaannya; (2) pelembagaan sistem pembangunan partisipatif; (3) pengefektifan fungsi dan peran pemerintahan lokal; (4) peningkatan kualitas dan kuantitas prasarana sarana sosial dasar dan ekonomi masyarakat; (5) pengembangan jaringan kemitraan dalam pembangunan. Dalam rangka mencapai visi dan misi PNPM Mandiri Pedesaan, strategi yang dikembangkan PNPM Mandiri Pedesaan yaitu menjadikan masyarakat miskin sebagai kelompok sasaran, menguatkan sistem pembangunan partisipatif, serta mengembangkan kelembagaan kerja sama antar desa. Berdasarkan visi, misi, dan strategi yang dikembangkan, maka PNPM Mandiri Pedesaan lebih menekankan pentingnya pemberdayaan sebagai pendekatan yang dipilih. Melalui PNPM Mandiri Pedesaan diharapkan masyarakat dapat menuntaskan tahapan pemberdayaan yaitu tercapainya kemandirian dan keberlanjutan, setelah tahapan pembelajaran dilakukan melalui Program Pengembangan Kecamatan (PPK). 
Program Penanggulangan Kemiskinan Perkotaan (P2KP) dilaksanakan di Provinsi Bali sejak tahun 1999 sebagai suatu upaya pemerintah untuk membangun kemandirian masyarakat dalam menanggulangi kemiskinan secara berkelanjutan. Pada tahun 2008 keberlanjutan P2KP di Provinsi Bali diperluas lagi menjadi PNPM Mandiri Perkotaan, dengan mengalokasikan tambahan dana yang cukup signifikan pada tahun anggaran 2008 yang mencakup 8.813 Kelurahan tersebar pada 245 kota/kabupaten (http://www.pnpm-perkotaan.org, 2014). Pelaksanaan PNPM Mandiri perkotaan ini mencakup serangkaian kegiatan yang berorientasi pada siklus rembug kesiapan masyarakat dan kerelawanan, refleksi kemiskinan, pemetaan swadaya berorientasi IPM-MDGs, pembentukan Badan Keswadayaan Masyarakat (BKM), perencanaan partisipatif menyusun Program Jangka Menengah Program Penanggulangan Kemiskinan (PJM Pronangkis) berorientasi kinerja peningkatan IPM-MDGs dan pelaksanaan program penanggulangan kemiskinan oleh masyarakat dengan stimulan Bantuan Langsung Masyarakat (BLM) oleh Kelompok Keswadayaan Masyarakat (KSM).

BLM adalah dana stimulan keswadayaan yang diberikan kepada kelompok masyarakat untuk membiayai sebagian kegiatan yang direncanakan oleh masyarakat dalam rangka meningkatkan kesejahteraan terutama masyarakat miskin. Dana BLM besifat stimulan untuk memberi peluang kepada masyarakat agar dapat secara nyata belajar melaksanakan dan mengelola kegiatan penanggulangan kemiskinan yang sudah direncanakan dan tercantum dalam PJM Pronangkis.

Sumber pendanaan kegiatan masyarakat dalam bentuk BLM PNPM Mandiri Perkotaan memakai pola dana pendamping (cost-sharing) antara pusat dengan daerah berdasarkan kapasitas fiskal masingmasing kabupaten sesuai Peraturan Menteri Keuangan Nomor 73/PMK.02/2006 tanggal 30 Agustus 2006. Sesuai dengan surat dari Departemen Pekerjaan Umum Nomor : PR.01.03-DC/664 tanggal 30 Nopember 2009 tentang lokasi dan alokasi PNPM Mandiri Perkotaan, Dana yang dialokasikan di Kota Denpasar pada Tahun 2010 Sebesar Rp. 3.830.000.000,- yang dapat terealisasi sebesar Rp. 2.820.000,- . Kemudian di tahun 2011 sesuai surat dari Kementerian Pekerjaan Umum Nomor : Ku.0809-C6/394 tanggal 14 April 2011 Perihal : Daftar rincian Lokasi dan Alokasi Dana BLM PNPM Mandiri Perkotaan T.A. 2011, besar Dana BLM yang dialokasikan di Kota Denpasar Sebesar Rp. 3.890.000.000,- yang terealisasi Rp. 2.701.217.000,-. Selanjutnya Pemerintah Kota Denpasar menindaklanjuti dengan menerbitkan Keputusan Walikota Nomor : 188.45/728/HK/2010 yang ditetapkan tanggal 24 November 2010 tentang Pembentukan Tim Kelompok Kerja Paket dalam Pelaksanaan Program Penanggulangan Kemiskinan di Perkotaan Kota Denpasar Tahun Anggaran 2010. Pada lima tahun terakhir rincian Realisasi dana BLM yang diterima pemerintah Kota Denpasar untuk Program Nasional Pemberdayaan Masyarakat Mandiri Perkotaan (PNPM MP) dapat dilihat pada Tabel 2.

Tabel. 2 Realisasi Dana BLM Kota Denpasar T.A 2010-2014

\begin{tabular}{|c|c|c|c|c|c|c|c|}
\hline \multirow{2}{*}{ No } & \multirow[t]{2}{*}{ Kecamatan } & \multicolumn{6}{|c|}{ Alokasi anggaran ( dalam ribu) } \\
\hline & & 2010 (Rp) & 2011(Rp) & 2012(Rp) & 2013(Rp) & 2014(Rp) & TOTAL(Rp) \\
\hline 1 & $\begin{array}{l}\text { Denpasar } \\
\text { Utara }\end{array}$ & 790,000 & 691,009 & 850,000 & 850,000 & 850,000 & $4,031,009$ \\
\hline 2 & $\begin{array}{l}\text { Denpasar } \\
\text { Timur }\end{array}$ & 750,000 & 691,009 & 750,000 & 825,000 & 825,000 & $3,841,009$ \\
\hline 3 & $\begin{array}{l}\text { Denpasar } \\
\text { Selatan }\end{array}$ & 600,000 & 628,190 & 600,000 & 750,000 & 750,000 & $3,328,190$ \\
\hline 4 & $\begin{array}{l}\text { Denpasar } \\
\text { Barat }\end{array}$ & 680,000 & 691,009 & 800,000 & 825,000 & 825,000 & $3,821,009$ \\
\hline \multicolumn{2}{|c|}{ Kota Denpasar } & 2.820 .000 & $2,701,217$ & $3,000,000$ & $3,250,000$ & $3,250,000$ & $15,021,217$ \\
\hline
\end{tabular}

Berdasarkan tabel 2 total realisasi BLM di Kota Denpasar adalah Rp.15.021.217.000,- dan realisasi jumlah orang yang dilibatkan dalam penerimaan bantuan PNPM Mandiri tersebut adalah 46.022 orang tersebar merata di seluruh Kota Denpasar. Secara rinci ralisasi penyebaran penerima BLM PNPM Mandiri Perkotaan dapat dilihat pada tabel 3. 
Tabel. 3 Lokasi dan Jumlah Penerima BLM Kota Denpasar Tahun 2010-2014

\begin{tabular}{|c|c|c|c|c|c|c|c|c|}
\hline \multirow{2}{*}{ No } & \multirow{2}{*}{\multicolumn{2}{|c|}{ Nama Daerah }} & \multicolumn{5}{|c|}{ Jumlah Penerima BLM (orang) } & \multirow{2}{*}{ Jumlah } \\
\hline & & & 2010 & 2011 & 2012 & 2013 & 2014 & \\
\hline 1 & $\begin{array}{l}\text { Kecamatan } \\
\text { Utara }\end{array}$ & Denpasar & 5.971 & 3.641 & 2.217 & 3.338 & 649 & 15.816 \\
\hline 2 & $\begin{array}{l}\text { Kecamatan } \\
\text { Timur }\end{array}$ & Denpasar & 4.659 & 2.270 & 1.227 & 431 & 348 & 8.935 \\
\hline 3 & $\begin{array}{l}\text { Kecamatan } \\
\text { Selatan }\end{array}$ & Denpasar & 4.338 & 1.739 & 1.085 & 2.047 & 265 & 9.474 \\
\hline 4 & $\begin{array}{l}\text { Kecamatan } \\
\text { Barat }\end{array}$ & Denpasar & 4.933 & 1.881 & 1.452 & 2.948 & 583 & 11.797 \\
\hline & Jumlah & & 19.901 & 9.531 & 5.981 & 8.764 & 1.845 & 46.022 \\
\hline
\end{tabular}

Menurut Sekretariat PNPM Mandiri Perkotaan Kota Denpasar, realisasi penerima manfaat BLM tahun 2010 di Kota Denpasar mencapai 19.901 orang yang tersebar di 4 Kecamatandan 43 Desa/Kelurahan. Kecamatan Denpasar Utara Merupakan Kecamatan dengan realisasi penerima manfaat terbesar di antara 4 Kecamatan di Kota Denpasar yaitu sebesar 5971 Orang. Dalam PNPM Mandiri perkotaan di Kota Denpasar, penanggulangan kemiskinan dilakukan dengan memberdayakan masyarakat melalui tiga jenis kegiatan pokok yaitu : perbaikan lingkungan (infrastruktur), sosial, dan ekonomi yang dikenal dengan tridaya. Total kegiatan yang sudah dilaksanakan berdasarkan program tridaya dapat dilihat pada Tabel 4 .

Tabel. 4 Rekapitulasi Kegiatan BLM Tridaya Tahun 2010-2014

\begin{tabular}{ccccc}
\hline Tahun & Lingkungan (keg) & Ekonomi (keg) & Sosial (keg) & Jumlah (keg) \\
\hline 2010 & 217 & 22 & 31 & 270 \\
2011 & 174 & 9 & 7 & 190 \\
2012 & 139 & 16 & 29 & 184 \\
2013 & 172 & 10 & 21 & 203 \\
2014 & 142 & 10 & 59 & 211 \\
\hline Jumlah & 844 & 67 & 147 & 1.058 \\
\hline
\end{tabular}

Berdasarkan Tabel 4 dapat dideskripsikan bahwa total kegiatan yang dilaksanakan selama empat tahun terakhir di Kota Denpasar adalah 1.058 kegiatan. Dari 1.058 kegiatan tersebut jumlah penduduk miskin yang terlibat mencapai 46.022 orang (Sekretariat PNPM Mandiri perkotaan Kota Denpasar, 2014). Salah satu jenis kegiatan tridaya yang sudah dilakukan di Kota Denpasar adalah PNM Mandiri Perkotaan bidang lingkungan (infrastruktur). Dalam pengambilan keputusan maupun pelaksanaan kegiatan yang menyangkut kepentingan masyarakat banyak, terutama kepentingan masyarakat miskin, maka didorong agar keputusan dan pelaksanaan kegiatan tersebut berorientasi pada upaya perlindungan/pemeliharaan lingkungan baik lingkungan alami maupun buatan termasuk perumahan dan permukiman, yang harus layak, terjangkau, sehat, aman, teratur, serasi dan produktif. Termasuk didalamnya adalah penyediaan prasarana dan sarana dasar perumahan yang kondusif dalam membangun solidaritas sosial dan meningkatkan kesejahteraan penduduknya.

Kegiatan infrastruktur yang sudah dibangun dari BLM PNPM Mandiri Perkotaan di Kecamatan Denpasar Utara dalam kurun waktu 2010 - 2014 antara lain: Pembangunan Drainase (47.913 m); Sumur Bor (118 unit); Sumur Umum (9 unit); Hidran Umum (6 unit); Jalan Rabat Beton (2.719 m); Jalan Sirtu (12.485 m); Jalan Paving Block (14.377 m); Jalan Onderlaagh (1.030 m); Jalan Lapen (300 m); Jembatan Beton (8 unit);Pembangunan Jembatan Gantung (1 unit); Rehab Jembatan Gantung (2 unit); Gedung Poskeskel (3 unit); Gedung Serba Guna (1 unit); Sarana MCK (15 unit); Tempat Pembuangan Sementara atau TPS (4 unit); Generator Penerangan (31 unit); Talud (1.142 m); Gorong-gorong Plat Decker (251 Unit) dan beberapa kegiatan infrastruktur ringan lainnya.

Jadi infrastruktur yang dibangun oleh PNPM Mandiri Perkotaan adalah infrastruktur dasar yang memiliki daya dukung terhadap pengembangan ekonomi dan akses masyarakat, seperti jalan dan jembatan. Kemudian, infrastruktur sanitasi untuk meningkatkan kualitas kesehatan masyarakat, seperti 
penyediaan air bersih melalui pembangunan sumur bor, hidran umum, sumur umum, drainase, goronggorong, sarana MCK, TPS dan gerobak sampah.

Disisi lain, PNPM Mandiri Perkotaan juga bertujuan untuk meningkatkan produktivitas kerja masyarakat. Produktivitas kerja masyarakat yang dimaksud adalah suatu kemampuan untuk melakukan kegiatan yang menghasilkan suatu produk atau hasil kerja sesuai dengan mutu yang ditetapkan dalam waktu yang lebih singkat sehingga senantiasa berkarya lebih dari apa yang telah dan sedang diusahakan dalam rangka mempercepat pencapaian tujuan dari suatu usaha. Faktor-faktor yang dapat mempengaruhi produktivitas kinerja adalah pendidikan, keterampilan, sikap dan etika kerja, tingkat penghasilan, jaminan sosial, tingkat sosial dan iklim kerja, motivasi, gizi dan kesehatan, hubungan individu, teknologi, dan produksi.

Konsep produktivitas erat hubungannya dengan efektivitas dan efisiensi. Efektivitas dan efisiensi yang tinggi akan menghasilkan produktivitas yang tinggi. Atinya apabila produktivitas naik hanya dimungkinkan oleh adanya peningkatan efisiensi (waktu, bahan, tenaga) dan sistem kerja, teknik produksi, dan adanya peningkatan keterampilan tenaga kerja. Dengan meningkatnya produktivitas kerja masyarakat, pertumbuhan ekonomi atau kesejahteraan masyarakat akan meningkat pula. Hal itu karena produktivitas kerja masyarakat akan meningkatkan pendapatan dan pertumbuhan ekonomi masyarakat.

Berdasarkan Tabel 2 sangat jelas dana yang dikeluarkan oleh pemerintah dalam penanggulangan kemiskinan di Kota Denpasar melalui PNPM Mandiri Perkotaan sangat besar dengan melibatkan jumlah orang yang sangat banyak. Jika dikaitkan dengan Tabel 1, Tabel 3 dan Tabel 4 dimana penduduk miskin, dan realisasi penerima manfaat BLM terbanyak berada di Kecamatan Denpasar Utara. Maka program PNPM MP di Kecamatan Denpasar Utara layak dan perlu dilakukan evaluasi. Evaluasi dapat dilakukan dengan melihat sejauh mana pengaruh PNPM MP dalam pengentasan kemiskinan di Kecamatan Denpasar Utara. Pengaruh tersebut dapat dilihat dari bagaimana pengaruh kegiatan yang dilaksanakan dalam PNPM Mandiri Perkotaan terhadap produktivitas kerja dan kesejahteraan masyarakat di Kecamatan Denpasar Utara. Oleh karena itu, dalam penelitian ini akan menganalisis sejauh mana pengaruh BLM PNPM Mandiri perkotaan dalam meningkatkan kesejahteraan masyarakat melalui produktivitas kerja masyarakat di Kecamatan Denpasar Utara. Dan jenis BLM yang diteliti akan difokuskan pada BLM bidang lingkungan (infratsruktur) di Kecamatan Denpasar Utara.

\section{Metode}

Penelitian ini adalah penelitian expost facto yang dilaksanakan di Kecamatan Denpasara Utara dengan melibatkan 11 keluarahan. Populasi dalam penelitian ini adalah 5971 orang dan sampelnya adalah 98 orang. Data dikumpulkan dengan menggunakan teknik kuesioner yang dipertegas dengan kegiatan observasi dan wawancara. Observasi lapangan dilakukan untuk mengumpulkan data yang berasal dari dokumen-dokumen yang berhubungan dengan rumusan masalah. Penyeberan kuesioner dilakukan untuk mendapat umpan balik dari masyarakat tetang progrma PNPM Mandiri Perkotaan. Kuesioner bisa dijawab sendiri atau dibantu oleh orang lain yang dipercaya. Wawancara mendalam merupakan proses mencari informasi secara mendalam, terbuka, bebas dengan masalah yang difokuskan dalam penelitian. Wawancara dilakukan dengan mengajukan beberapa pertanyaan yang sebelumnya telah disusun untuk ditanyakan kepada informan sebagai acuan dan sifatnya tidak mengikat sehingga banyak pertanyaan baru yang muncul pada saat wawancara. Informan yang dimaksudkan antara lain tokoh-tokoh masyarakat, dan lain-lainnya yang memiliki kemampuan untuk menjelaskan tentang pokok permasalahan yang dicari. Data yang dikumpulkan dalam penelitian adalah data primer yang diperoleh melalui kuesioner tertutup dengan skala Linkert yang mana masing-masing variabel berjumlah 30 item. Sebelumnya kuesioner tersebut sudah uji validtas dan reliabilitasnya. Kuesioner ini merupakan persepsi dari responden tentang variabel penelitian yang kemudian dikuantifikasikan agar dapat dilakukan uji statistik. Untuk menguji kelayakan instrumen tersebut dilakukan validasi instrumen, yang meliputi uji validitas dan reliabilitas instrumen. Untuk validasi instrumen, instrumen di uji cobakan di masyarakat penerima PNPM Mandiri di Kecamatan Denpasar Utara. Hasil uji coba masing-masing variabel dapat dijelaskan sebagai berikut.

\section{Hasil dan Pembahasan}

Analisis Deskriptif variabel bertujuan untuk membuat analisis terhadap jawaban tiap-tiap instrumen dengan menggunakan skor rata-rata sehingga dapat diketahui posisi kinerja tiap-tiap instrumen yang membentuk dimensinya. Pada akhirnya nilai total yang diperoleh dari penjumlahan ratarata skor tiap-tiap instrumen membentuk skor penilaian bagi tiap-tiap dimensi (variabel laten). Tinggi rendahnya nilai total yang diperoleh oleh tiap-tiap instrumen ditentukan oleh proposi jawaban responden sesuai dengan skala penilaian (sangat setuju, setuju, cukup, tidak setuju, sangat tidak setuju). 
Analisis deskriptif dalam penelitian ini dilakukan untuk memperoleh gambaran yang menyeluruh tentang Program PNPM Mandiri Perkotaan bidang infrastruktur di Kecamatan Denpasar Utara yang dikaitkan dengan kesejahteraan masyarakat, produktivitas dan kemandirian masyarakat. Analisis deskriptif dalam penelitian ini didasarkan atas data yang dihimpun melalui kuesioner, seperti terlihat pada Tabel 5.

Tabel. 5 Hasil Analisis Deskriptif Masing-Masing Variabel Penelitian

\begin{tabular}{llccccc}
\hline No & Varabel Penelitian & $\begin{array}{c}\text { Item } \\
\text { Pertanyaan }\end{array}$ & $\begin{array}{l}\text { Kisaran } \\
\text { Teoritis }\end{array}$ & $\begin{array}{l}\text { Kisaran } \\
\text { Aktual }\end{array}$ & $\begin{array}{l}\text { Rata-rata } \\
\text { skor total }\end{array}$ & $\begin{array}{l}\text { Standar } \\
\text { Deviasi }\end{array}$ \\
\hline 1 & $\begin{array}{l}\text { Kesejahteraan } \\
\text { masyarakat }\end{array}$ & 8 & $8-40$ & $19-40$ & 4,165813 & 4,09620 \\
2 & $\begin{array}{l}\text { PNPM Mandiri Bidang } \\
\text { Infrastruktur }\end{array}$ & 11 & $11-55$ & $31-55$ & 4,068645 & 5,14143 \\
3 & \begin{tabular}{l} 
Produktivitas kerja \\
\hline
\end{tabular} & 7 & $7-35$ & $18-35$ & 4,243443 & 3,41074 \\
\hline
\end{tabular}

Tabel 5 mendeskripsikan bahwa berdasarkan hasil pengumpulan kuesioner diperoleh kesejahteraan masyarakat di Kecamatan Denpasar Utara berada diantara nilai kisaran aktual minimum dengan skor 19 dan skor 40 untuk kisaran aktual maksimum. Skor rata - rata keseluruhan alat ukur yang digunakan untuk mengukur kesejahteraan masyarakat di Kecamatan Denpasar Utara sebesar 4,165813 dengan standar deviasi 4,09620 tergolong baik. Jika dibuatkan dalam bentuk grafik dapat disajikan seperti Gambar 1.

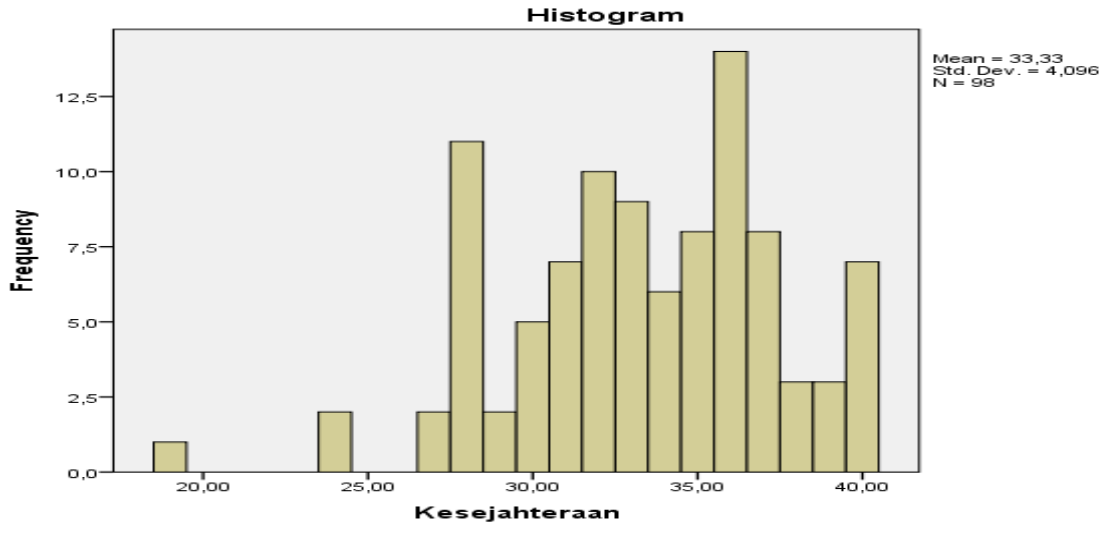

Gambar 1 Histogram Kesejahteraan masyarakat Pemerintah

Nilai kisaran aktual pelaksanaan program PNPM Mandiri Bidang Infrastruktur minimum 31 dan maksimum 55. Skor rata - rata keseluruhan alat ukur yang digunakan untuk mengukur program PNPM Mandiri Bidang Infrastruktur di Kecamatan Denpasar Utara sebesar 4,068645, dengan standar deviasi 5,14143 tergolong baik. Jika dibuatkan dalam bentuk grafik dapat disajikan seperti Gambar 2.

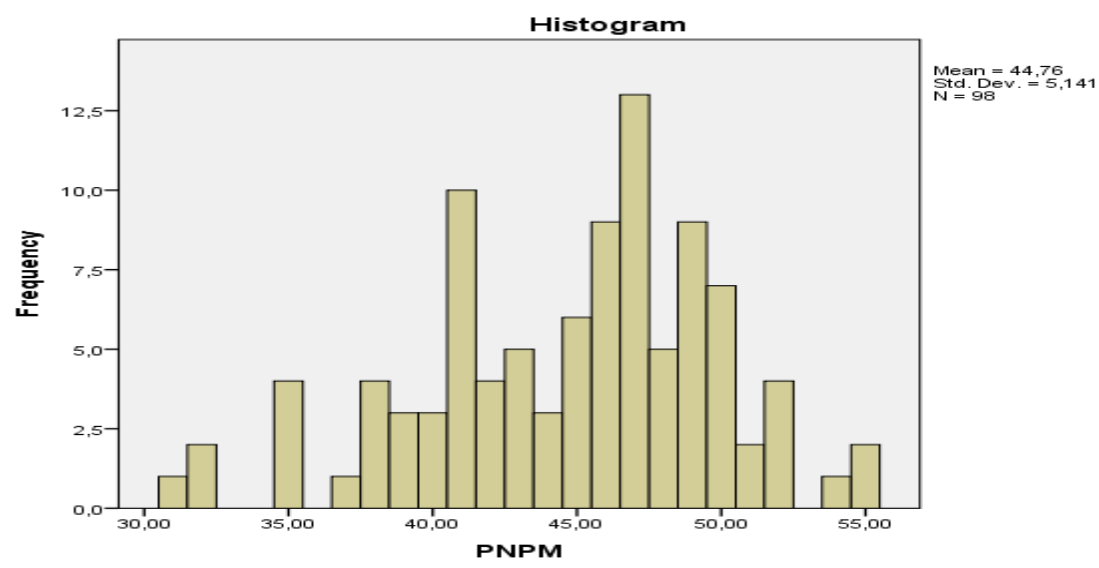

Gambar 2 Historgram Variabel PNPM Mandiri Bidang Infrastruktur

Nilai kisaran aktual produktivitas kerja yaitu masing - masing skor 18 untuk kisaran aktual minimum dan 35 untuk kisaran aktual maksimum. Skor rata - rata keseluruhan alat ukur yang digunakan 
untuk mengukur Produktivitas kerja Di Kecamatan Denpasar Utara sebesar 4,243443, dengan standar deviasi 3,41074 tergolong baik. Jika dibuatkan dalam bentuk grafik dapat disajikan seperti Gambar 3.

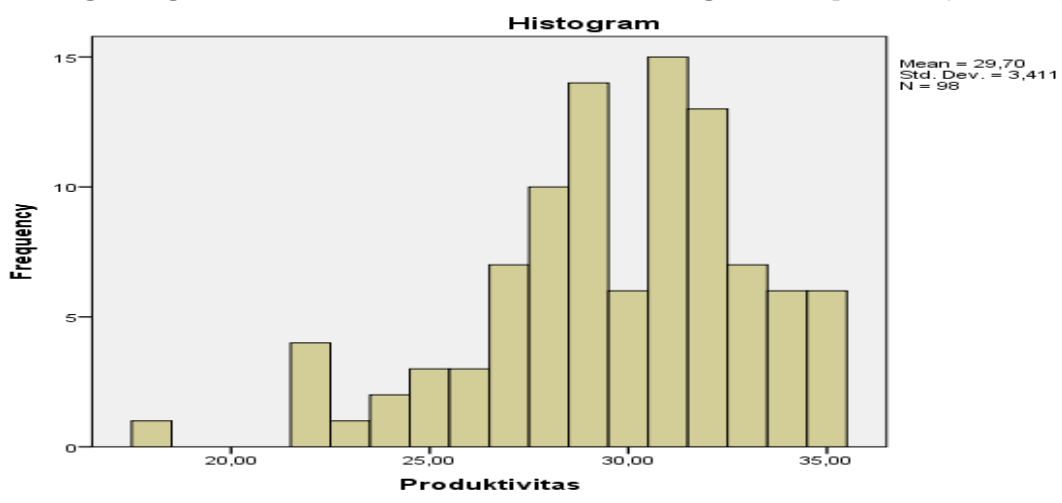

Gambar 3 Historgram Variabel Produktivitas kerja

Model pengukuran untuk analisis faktor konfirmatori dilakukan secara terpisah untuk konstrukkonstruk eksogen dan endogen dimana prosedur analisis konfirmatori mengacu pada analisis overall model fit, analisis factor loading dan signifikansi factor loading (Hair et.al, 1995). Sebelum dilakukan analisis konfirmatori terlebih dahulu akan dilakukan pengujian undimensional variabel eksogen.

GFI adalah sebuah ukuran non statistical yang mempunyai rentang nilai antara 0 (poor fit) sampai dengan 1,0 (perfect fit). Nilai yang tinggi dalam indeks ini menunjukkan sebuah better fit. GFI merupakan analog dari $\mathrm{R}^{2}$ dalam regresi berganda. AGFI untuk menguji diterima tidaknya model, bahwa tingkat peneriman yang direkomendasikan adalah apabila AGFI mempunyai nilai lebih besar atau sama dengan 0,547. Dari Gambar 2 dapat dilihat bahwa ketiga variabel yaitu Program PNPM Mandiri Perkotaan bidang infrastruktur, Produktivitas dan Kesejahteraan Masyarakat memiliki nilai GFI mendekati nilai 1 (perfect fit), maka syarat yang diinginkan sudah terpenuhi. Jadi dapat disimpulkan bahwa ketiga variabel tersebut adalah fit.

Berdasarkan hasil output dari SEM pada Gambar 3 yaitu output model fit, maka dibuatkan rangkuman hasil Indeks Pengujian Kelayakan Struktural Equation Model dari masing-masing output. RMSEA adalah sebuah indeks yang dapat digunakan untuk mengkompensasi chi square statistic dalam sampel yang besar. Nilai RMSEA menunjukkan Goodness of fit yang dapat diharapkan bila model estimasi dalam populasi. Berdasarkan Tabel 5 kriteria RMSEA dapat dikatakan dapat diterima secara marginal karena nilainya lebih besar atau sama dengan dari 0,08. Nilai 0,08 merupakan indeks untuk dapat diterimanya model yang menunjukkan sebuah close fit dari model itu berdasarkan degree of freedom (Browne \& Cudeck, 1993). Hasil pengolahan model SEM dapat ditunjukkan pada Gambar 4 dan tabel 6.
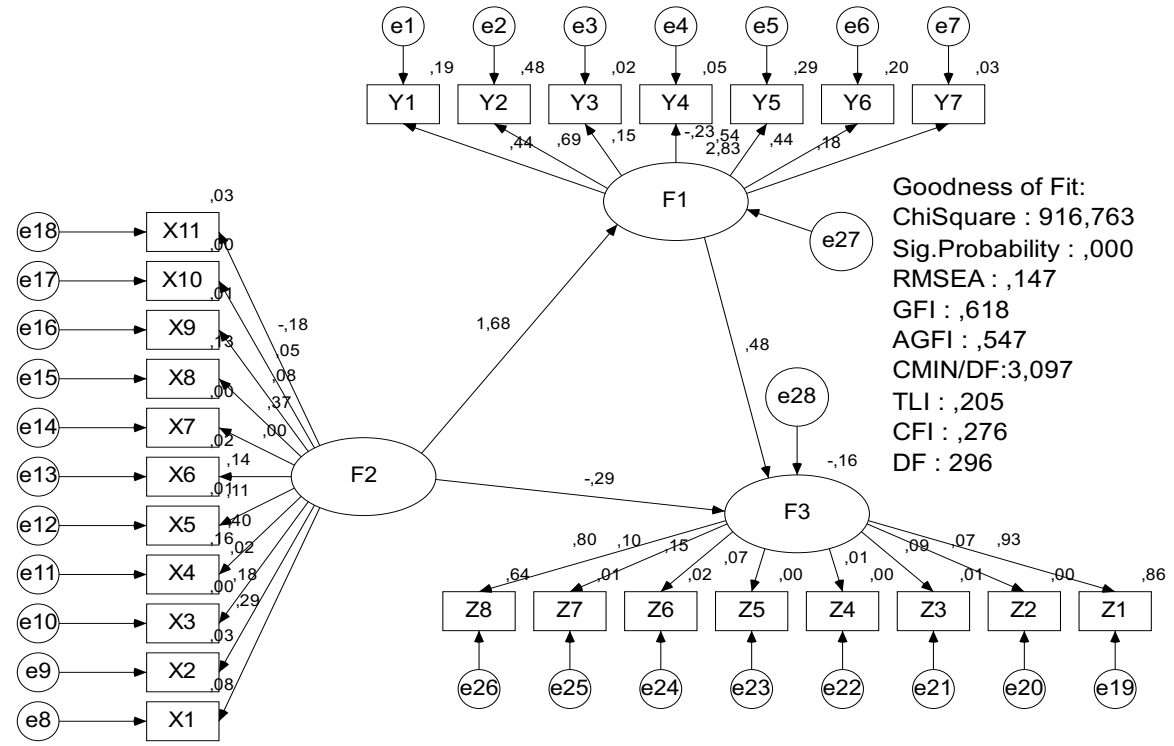

Gambar 4. Hasil Pengolahan Data dengan SEM 
Tabel 6. Hasil Pengolahan Data dengan SEM

\begin{tabular}{crrr}
\hline Goodness of Fit Index & Cutt- of Value & Hasil Analisis & Evaluasi Model \\
\hline RSMEA & $\leq 0,08$ & 0,147 & Marginal \\
GFI & $\geq 0,90$ & 0,618 & Marginal \\
AFGI & $\geq 0,90$ & 0,547 & Marginal \\
CMIN/DF & $\geq 2,00$ & 3,097 & Marginal \\
\hline
\end{tabular}

GFI adalah sebuah ukuran non statistical yang mempunyai rentang nilai antara 0 (poor fit) sampai dengan 1,0 (perfect fit). Nilai yang tinggi dalam indeks ini menunjukkan sebuah better fit. GFI merupakan analog dari $\mathrm{R}^{2}$ dalam regresi berganda. AGFI untuk menguji diterima tidaknya model, bahwa tingkat peneriman yang direkomendasikan adalah apabila AGFI mempunyai nilai lebih besar atau sama dengan 0,90. Dalam penelitian ini nilai GFI dan AGFI diterima secara marginal. Jadi dapat disimpulkan bahwa uji terhadap model menunjukkan bahwa model ini cukup fit terhadap data yang digunakan dalam penelitian ini. SEM sebagaimana analisis multivariate lainnya mensyaratkan terpenuhinya berbagai asumsi meskipun SEM dipandang fleksibel (interpretasi tetap dapat dilakukan meskipun ditemukan problem multikolinearitas). Asumsi-asumsi penting yang harus dipenuhi dalam SEM adalah distribusi data-data yang muncul (khusus normalitas dan multivariate), tidak ada multikolinearitas maupun singularitas dan tidak ada outlier. Asumsi normalitas data harus dipenuhi agar data dapat diolah lebih lanjut untuk permodelan SEM. Jika teknik estimasi yang digunakan adalah MLE (Maximum Likelihood Estimation), maka asumsi multivariate normality mutlak harus dipenuhi (Hair et al, 1995).

SEM mensyaratkan dipenuhinya asumsi normalitas. Untuk menguji normalitas distribusi data dapat digunakan uji statistik. Uji yang paling mudah adalah dengan mengamati kurtosis dari data yang digunakan. Nilai statistik yang digunakan untuk menguji normalitas itu disebut Z-value. Bila nilai Z lebih besar dari nilai kritis maka dapat diduga bahwa distribusi data tidak normal. Nilai teoritis dapat ditentukan berdasarkan tingkat signifikansi yang dikehendaki. Normalitas data dapat ditunjukkan dengan adanya Critical Ratio (CR) dengan nilai ambang batas sebesar $\pm 2,58$ pada tingkat signifikansi $0,01(1 \%)$ (Ferdinan, 2000). Tabel 5. menunjukkan bahwa tidak terdapat CR yang nilanya melebihi $\pm 2,58$. Jadi dapat disimpulkan bahwa asumsi normalitas terpenuhi. (ada beberapa data yang di atas 3).

Outlier adalah observasi yang muncul dengan nilai-nilai ekstrim baik secara univariat maupun multivariat yaitu yang muncul karena kombinasi karakteristik unik yang dimilikinya dan terlihat sangat jauh berbeda dari observasi-observasi lainnya. Pada dasarnya outlier dapat muncul dalam 4 hal. Pertama, outlier muncul karena kesalahan dalam mengkoding data. Kedua, outlier dapat muncul karena keadaan yang benar-benar khusus yang memungkinkan profil datanya lain daripada yang lain, tetapi peneliti mempunyai penjelasan mengenai penyebab munculnya nilai ekstrim ini. Ketiga, outlier dapat muncul karena adanya sesuatu alasan tetapi peneliti tidak dapat mengetahui apa penyebabnya atau tidak ada penjelasan mengenai sebab-sebab munculnya nilai ekstrim ini. Keempat, outlier dapat muncul dalam range nilai yang ada, tetapi bila dikombinasi dengan variabel lainnya kombinasinya menjadi tidak lazim atau sangat ekstrim (Ferdinand, 2000).

Evaluasi terhadap multivariate outliers perlu dilakukan sebab kendati data yang dianalisis menunjukkan tidak ada outlier pada tingkat univariat, observasi tersebut bisa menjadi outlier bila sudah saling dikombinasikan (Ferdinand, 2000). Uji outlier multivariate dilakukan dengan menggunakan kriteria jarak mahalonobis pada tingkat $\mathrm{p}<0,01$ dengan 26 indikator yang digunakan dalam penelitian ini adalah $\chi^{2}(26 ; 0,01)=34,805$. Jarak mahalanobis ini dievaluasi dengan menggunakan chi-square pada derajat bebas sebesar jumlah indikator yang digunakan dalam penelitian. Data yang memiliki jarak mahalanobis yang lebih besar dari 45,647 merupakan multivariate outlier.

Dalam proses analisis tidak ditemukan data yang outlier, dimana data mahalanobis distance tidak ada yang nilainya lebih dari 69,647. Pengujian kesesuaian model penelitian adalah untuk menguji seberapa baik tingkat goodness of fit dari model penelitian, penelitian ini digunakan beberapa kriteria yang disyaratkan oleh SEM dari hasil pengolahan data kemudian dibandingkan dengan batas statistik yang telah ditentukan. Model yang baik mempunyai Standardized Residual Covariances yang kecil. Angka sebesar 2.58 merupakan batas nilai Standardized Residual yang disyaratkan. Nilai residual values yang lebih besar atau sama dengan $\pm 2,58$ diinterpretasikan sebagai signifikan secara statistik pada tingkat $1 \%$ (Ferdinand, 2000). Pengujian terhadap nilai residual tersebut menunjukkan bahwa model tersebut sudah signifikan karena tidak ada angka yang lebih besar dari $\pm 2,58$. Dengan demikian, model ini tidak perlu dimodifikasi.

Setelah asumsi permodelan SEM terpenuhi, maka selanjutnya akan dilakukan analisis dan interpretasi terhadap parameter estimasi (standardized regression weight) antar konstruk laten. Parameter estimasi antar variabel laten yang dimaksudkan untuk menguji hipotesis-hipotesis yang 
diajukan dalam penelitian ini. Adapun hasil estimasi untuk parameter estimasi antar variabel laten beserta keputusan yang diambil.

Berdasarkan hasil ouput terlihat bahwa ketiga variabel berhubungan nyata dan signifikansi pada alpha 5\% yaitu hubungan antara Program PNPM Mandiri Perkotaan bidang infrastruktur dengan Produktivitas, Kesejahteraan Masyarakat dengan Program PNPM Mandiri Perkotaan bidang infrastruktur dan hubungan antara Produktivitas dengan Kesejahteraan Masyarakat. Berdasarkan Tabel 5, dapat dilihat bahwa semua indikator berpengaruh secara signifikan dilihat dari nilai probabilitasnya yang kurang dari 5\%. Indikator yang berkontribusi paling tinggi dilihat pada Hal ini menunjukkan bahwa ketika melakukan pendekatan kepada masyarakat berjalan sukses namun ketika eksekusi program berjalan dengan tidak efektif, mulai dari ketidaksesuaian anatar program dengan realita sampai pada keterlambatan pelaksanaan program. Oleh sebab itu, masyarakat lebih memilih untuk memberi sumbangan berupa material seperti makanan dan minuman pada saat pelaksanaan kegiatan PNPM Mandiri Perdesaan berlangsung. Dalam hal sosialisasi masyarakat masih kurang tahu tentang adanya PNPM itu sendiri.

Indikator yang berkontribusi paling tinggi pada variabel Produktivitas adalah kompetensi professional masyarakat (skill masyarakat) dan paling rendah adalah pemahaman atas pekerjaanya sendiri. Dapat dilihat bahwa masyarakat memiliki skill yang bagus terhadap pekerjaanya tetapi tidak memahami secara utuh begaimana pekerjaan yang dilakoninya.

Indikator yang berkontribusi paling tinggi pada variabel Kesejahteraan Masyarakat adalah kemudahan dalam mendapatkan alat transportasi dan yang paling rendah adalah kesulitan mendapatkan tempat tinggal yang layak huni. Kebanyakan masyarakat di Kecamatan Denpasar Utara memiliki kendaraan sebagai alat transportasi tetapi tidak memiliki tempat huni yang layak.

Berdasarkan Tabel 5 mengenai rangkuman hasil kuiesioner berdasarkan skala likert dapat dilihat bahwa pada Program PNPM Mandiri Perkotaan bidang infrastruktur kecenderungan masyarakat memilih jawaban $\mathbf{S}$ dan $\mathbf{R}$, dimana dalam skala likert jawaban tersebut memiliki skor yang sedang, jadi partisipasi msyarakat dapat digolongkan sedang, dukungan masyarakat kepada seorang pemimpin dapat dikatakan tinggi, begitu pula Kesejahteraan Masyarakat yang dikategorikan cukup tinggi karena kecenderungan masyarakat memilih jawaban SS dan $\mathbf{R}$.

Pengujian hipotesis didasarkan atas pengolahan data penelitian dengan menggunakan alat analisis SEM dengan cara menganalisis nilai regresi pengujian hipotesis dilakukan dengan melihat nilai CR dan nilai P pada hasil Regresion Weights Full Model, dibandingkan dengan batas statistik yang disyaratkan, nilai probabilitas kurang dari dari 0,05 Apabila hasil Regresion Weights Full Model menunjukkan nilai yang memenuhi syarat tersebut, maka hipotesis penelitian akan diterima.

Hipotesis 1: Program PNPM Mandiri Perkotaan bidang infrastruktur berpengaruh positif terhadap Produktivitas di Kecamatan Denpasar Utara. Dari Tabel 5 tersebut terlihat bahwa hubungan antara Program PNPM Mandiri Perkotaan bidang infrastruktur dan Produktivitas ditunjukkan dengan nilai probabilitas sebesar 0,019 yang signifikan pada alpha 0,05 (5\%). Jadi dapat ditarik kesimpulan bahwa Program PNPM Mandiri Perkotaan bidang infrastruktur berpengaruh positif terhadap Produktivitas di Kecamatan Denpasar Utara. Hasil pengujian Hipotesis pertama yang diterima membuktikan bahwa Program PNPM Mandiri Perkotaan bidang infrastruktur berpengaruh positif terhadap Produktivitas di Kecamatan Denpasar Utara. Faktor Program PNPM Mandiri Perkotaan bidang infrastruktur ikut mempengaruhi karena dalam salah satu kunci kesuksesan keberhasilan produktivitas mayarakat dalam bekerja dapat dilihat pada adanya Program PNPM Mandiri Perkotaan bidang infrastruktur yang dapat digunakan atau difungsikan dengan baik oleh masyarakatnya terutama dalam membantu pekerjaan sehari-hari masyarakat.

Hipotesis 2: Produktivitas berpengaruh positif terhadap Kesejahteraan Masyarakat PNPM Mandiri Perdesaan di Kecamatan Denpasar Utara. Dari tabel 5 tersebut terlihat bahwa hubungan Produktivitas dan Kesejahteraan Masyarakat dengan nilai probabilitas sebesar 0,017 yang signifikan pada alpha 0,05 (5\%). Dengan demikian $\mathrm{H}_{2}$ yang menyatakan Produktivitas berpengaruh positif terhadap Kesejahteraan Masyarakat. Hasil pengujian hipotesis kedua yang diterima membuktikan adanya hubungan positif antara Produktivitas dan Kesejahteraan Masyarakat. Hal ini menujukkan bahwa peran Produktivitas kerja sangat penting untuk meningkatkan kesejahteraan masyarakat.

Hipotesis 3: Program PNPM Mandiri Perkotaan bidang infrastruktur berpengaruh positif terhadap Kesejahteraan Masyarakat PNPM Mandiri Perdesaan di Kecamatan Denpasar Utara. Dari Tabel 5 tersebut terlihat bahwa hubungan Program PNPM Mandiri Perkotaan bidang infrastruktur terhadap Kesejahteraan Masyarakat PNPM Mandiri Perdesaan di Kecamatan Denpasar Utara dengan nilai probabilitas sebesar 0,034 yang signifikan pada alpha 0,05 (5\%). Dengan demikian H2 yang menyatakan bahwa Program PNPM Mandiri Perkotaan bidang infrastruktur berpengaruh positif terhadap Kesejahteraan Masyarakat PNPM Mandiri Perdesaan di Kecamatan Denpasar Utara. Hasil pengujian hipotesis yang diterima ini membuktikan bahwa Program PNPM Mandiri Perkotaan bidang infrastruktur 
berpengaruh positif terhadap Kesejahteraan Masyarakat PNPM Mandiri Perdesaan di Kecamatan Denpasar Utara. Apabila terjadi perubahan pada Program PNPM Mandiri Perkotaan bidang infrastruktur maka Kesejahteraan Masyarakatnya pun akan berubah. Perubahan yang terjadi searah karena kedua persamaan tersebut bertanda positif sehingga peningkatan pada Program PNPM Mandiri Perkotaan bidang infrastruktur akan membawa peningkatan pada pencapaian Kesejahteraan Masyarakat. Dengan kata lain semakin tinggi Program PNPM Mandiri Perkotaan bidang infrastruktur pada proyek PNPM Mandiri Pedesaan maka akan semakin tercapai tingkat keberhasilan dari proyek tersebut. Hal sebaliknya terjadi jika partisipasi warga menurun atau lebih rendah.

\section{Simpulan dan Saran}

Berdasarkan hasil dan pembahasan maka dapat disimpulkan beberapa hal sebagai berikut. Program PNPM Mandiri Perkotaan bidang infrastruktur berpengaruh positif terhadap Produktivitas di Kecamatan Denpasar Utara. Produktivitas berpengaruh positif terhadap Kesejahteraan Masyarakat PNPM Mandiri Perdesaan di Kecamatan Denpasar Utara. Program PNPM Mandiri Perkotaan bidang infrastruktur berpengaruh positif terhadap Kesejahteraan Masyarakat PNPM Mandiri Perdesaan di Kecamatan Denpasar Utara.

Berasarkan simpulan hasil penelitian di atas maka dapat direkomendasikan beberapa saran untuk implementasi hasil penelitian dan pengembangan hasil penelitian lebih lanjut sebagai berikut. pertama Bagi Aparatur Pemerintah. Hasil penelitian ini menunjukkan bahwa terdapat pengaruh positif antara PNPM Mandiri Perkotaan bidang Infrastruktur terhadap kesejahteraan masyarakat secara langsung maupun tidak langsung melalui produktivitas kerja masyarakat. Oleh sebab itu disarankan Bagi aparatur pemerintah secara umum dan pemerintah kecamatan Denpasar Utara secara khusus agar menggunakan hasil penelitian ini sebagai dasar untuk mengambil kebijakan dalam meningkatkan kesejahteraan masyarakatnya, misalnya dengan memperhatikan variabel yang berkaitan dengan PNPM Mandiri Perkotaan bidang Infrastruktur, produktivitas kerja masyarakat. Hal itu dapat dilakukan melalui berbagai pelatihan dan pendidikan yang disertakan dalam program PNPM Mandiri baik dengan materi eksplisit maupun dengan materi implisit. Kedua Bagi peneliti lain dan praktisi manajemen.

Untuk pengembangan penelitian lebih lanjut agar memperhatikan hal-hal sebagai berikut. (a) Penelitian ini dimaksudkan untuk mencari kejelasan pengaruh PNPM Mandiri Perkotaan bidang Infrastruktur terhadap kesejahteraan masyarakat, baik secara langsung maupun melalui produktivitas kerja masyarakat. Banyak variabel lain yang juga mungkin mempengaruhi hubungan antara PNPM Mandiri Perkotaan bidang Infrastruktur terhadap kesejahteraan masyarakat, seperti diantarannya faktor sosial, pendidikan, kemandirian, dan lingkungan yang berhubungan dengan pekerjaan (job relevant information), pusat kendali (locus of control) dan lain sebagainya tidak diungkap dalam penelitian ini. disarankan untuk penelitian lebih lanjut agar mengungkap variabel lain yang berkaitan dengan penelitian ini. (b) Populasi penelitian ini hanya difokuskan pada masyarakat penerima bantuan langsung masyarakat di kecamatan Denpasar Utara, tanpa melihat unsur - unsur lain yang terlibat langsung maupun tidak langsung yang berkaitan dengan kesejahteraan masyarakat disarankan untuk penelitian lebih lanjut menggunakan ruang lingkup yang lebih luas dan berbeda sehingga fokus penelitian menjadi lebih luas. Dan (c) Instrumen penelitian yang digunakan dalam penelitian ini hanya terbatas pada penggunaan kuesioner dengan penilaian secara persepsi pribadi (self rating), tanpa melakukan wawancara mendalam dengan para responden, sehingga faktor subjektivitas dan kemungkinan responden tidak memperlihatkan kesungguhan dapat mempengaruhi hasil penelitian ini. disarankan untuk penelitian selanjutnya agar menggunakan instrumen lain dalam pengumpulan data.

\section{Daftar Pustaka}

Aisyiah. (2001). Potret Kemiskinan dalam Jurnal Ekonomi Pembangunan, Surakata FE UMS, Vol 2 (8), 6284.

Akyeampong, K,. Djangmah, J., Seidu, A., Oduro,A. and Hunt,F. (2007) Access to Basic Education In Ghana : The Evidence And The Issues. Available At www.create-rpc.org

Amartya Sen. (2008) Perkembangan dan prospek kemandirian pangan, PT Citra Praya, bandung Anoraga, Panji. (1997). Manajemen Bisnis. Cet1. Jakarta: Rineka Cipta 
Angahar. Paul A. (2012). "Personal income tax administration in Nigeria: challenges and prospects for increased revenue generation from self employed persons in the society", Global Business and Economics Research Journal. Vol: 1. No. 1. hlm. 1-11.

Adrian Payne. (2007). The Essence of Service Marketing (Pemasaran Jasa). Jakarta: Salemba Empat.

Ambar Teguh Sulistyani. (2004). Kemitraan dan Model-Model Pemberdayaan, Gaya. Yogyakarta: Gava Media.

Angahar. Paul A. (2012). "Personal income tax administration in Nigeria: challenges and prospects for increased revenue generation from self employed persons in the society", Global Business and Economics Research Journal. Vol: 1. No. 1. hlm. 1-11.

Ardiawan, Muhammad. (2007). Dampak Bantuan Modal Kerja Bergulir Program Penanggulangan Kemiskinan Perkotaan (P2KP) Bagi Usaha Kecil Menengah (UKM) Terhadap Peningkatan Pendapatan Penerima Bantuan Di Kecamatan Abeli Kota Kendari, Tesis, Sekolah Pascasarjana UGM : Yogyakarta.

Bappeda Denpasar. (2008). Perencanaan Jangka Menengah Program Nasional Pemberdayaan Masyarakat Mandiri Perkotaan (PJM-PNPM) :Kota Denpasar.

BPS. (2004). Profil Usaha Kecil dan Menengah, Badan Pusat Statistik : Jakarta.

Badrudin. (2013). Dasar-dasar Manajemen. Bandung: Alfabeta

Bappenas. (2004). Rencana Pembangunan Jangka Menengah Nasional. Jakarta : Bappenas

Bintarto, R. (1989). Interaksi Desa-Kota dan Peermasalahannya. Jakarta: Ghalia Indonesia.

Blocher, Edward J, Chen, Kung H, Cokins, Gary, Lin Thomas W. (2007). "Manajemen Biaya Penekanan Strategis" ,Edisi Ketiga, Salemba Empat, Jakarta.

Brown, T. (2005). Empower the People. New York: Quill William Morrow.

Chambers, Robert. (2005). Poverty and Livelihood: Whose Reality Counts, Discussion Paper 347, Brighton : Institute of Development Studies.

Cornwall, A. dan Brock, K. (2005). "What do Buzzword do for Development Policy? A Critical Look at 'Participation', 'Empowerment' and 'Poverty Reduction', Third World Quarterly, Vol: 26. No. 7. hlm. 1043-1060.

Cox. (2004). Poverty alleviation programs in the Asia-Facific Region ,Seminar, $3^{\text {rd }}$ March : Jakarta.

Dale Timpe. (1992). Kinerja; penerjemah, Sofyan Cikmat, Seri 6 : Manajemen Sumber Daya Manusia, Jakarta : Elex Media Komputindo.

Departemen Dalam Negeri Republik Indonesia. (2008). Petunjuk Teknis Operasional Program Nasional Pemberdayaan Masyarakat-Mandri Perdesaan, Jakarta

Dunham, B.R., Jean, A.C., and Maria, B.C. (1999). Organizational Comitment : The Utility of an Integrative Definition. Journal of Applied Psychology. Vol. 79: 370 - 380.

Eyben, R., T. Kidder, J. Rowlands, and A. Bronstein. (2008). "Thinking about change for development practice: a case study from Oxfam GB". Development in Practice, Vol: 18. No. 2. hlm. 201-212.

Friedmann, John Empowermen. (2002). The Politics of Alternative Development, Blackwell : Cambridge.

Friedmann, John. (2002). Empowerment: The Politics of Alternative Development. Chambridge: Blackwell Publishers.

Friedman. (2004). Family Nursing Research Theory and Practice. $5^{\text {th }}$ Ed. Stamford : Appieton \& lange

Hadi, A.P. (2009). Tinjauan Terhadap Berbagai Program Pemberdayaan Masyarakat Indonesia, Yayasan Agribisnis/Pusat Pengembangan Masyarakat Agrikarya (PPMA)

Hadiyanti, P. (2006). Kemiskinan dan Upaya Pemberdayaan Masyarakat, Jurnal Pengembangan Masyarakat Islam, Vol. 2 No 1: Hal 33.

Harumy, T. Henny Febriana., Syaad Affifuddin, Rujiman. (2013). Analisis Pengaruh Bantuan Modal Sosial Terhadap Peningkatan Nilai Tambah Produk UMKM dan Kesejahteraan Masyarakat di Kabupaten langkat. Jurnal. Jurnal Eksis Volume 1 No 4 November 2013. 
Handari Nawawi. (1990). Administrasi Personel untuk Peningkatan Produktivitas Kerja. Jakarta : Haji Masagung.

Hikmat, H. (2004). Strategi Pemberdayaan Masyarakat. Bandung: Humaniora.

Husein, Umar. (1999). Riset SDM dalam Organisasi. Jakarta: PT. Gramedia Pustaka Utama Jakarta.

Ibrahim F. Akoum. (2008) Globalization, growth, and poverty: the missing link. : International Journal of Sosial Ekonomi Volume: 35 Issue: 4 2008. http://ww. emeraldinsight.com/journals.htm? articleid $=1889581$

Keputusan Walikota Nomor : 188.45/728/HK/2010 yang ditetapkan tanggal 24 November 2010 tentang Pembentukan Tim Kelompok Kerja Paket dalam Pelaksanaan Program Penanggulangan Kemiskinan di Perkotaan Kota Denpasar Tahun Anggaran 2010

Kementrian Pekerjaan Umum. (2012). Pedoman teknis tri daya (Sosial, Ekonomi, dan Lingkungan).

Komaruddin. (1992), Ensiklopedia Manajemen, Jakarta: Bumi Askara.

Krisno Dwipoyono, I Gusti Bagus. (2009). Efektivitas Penyaluran dan Dampak Bantuan Penanggulangan Kemiskinan Perkotaan (P2KP) Terhadap Pendapatan dan Kesempatan Kerja Rumahtangga Miskin di Kota Denpasar, Tesis Program Pasca Sarjana Magister Ekonomi Pembangunan, Denpasar : Universitas Udayana

Kuncoro, Mudrajad. (2001). Metode kuantitatif teori dan aplikasi untuk bisnis dan ekonomi edisi pertama, AMP YKPN: Jakarta.

Kusriyanto, Bambang. (1993). Meningkatkan Produktivitas Karyawan, Jakarta, PT. Pustaka Binaman Pressindo

Midgley,james. (2005). Pembangunan Sosial, perspektif pembangunan dalam kesejahteraan sosial. Jakarta : Ditperta Islam

Moekijat. (1998). Analisis Jabatan. Bandung : Penerbit Mandar Maju.

Muchdarsyah Sinungan. (2005). Produktivitas. Jakarta: Bumi Aksara

Muhadjir, Noeng. (2006). Metodologi Penelitian Kualitatif, Yogyakarta: Penerbit Rave Sarasin.

Muhajir Efendi. (2002). Masyarakat Equilibrium Yogyakarta: Bentang Budaya.

Mulia Nasution. (1994). Manajemen Personalia. Jakarta: Erlangga.

Nasikun. (1993). Sistem sosial indonesia. Jakarta: PT. Raja Grafindo

Ravianto, S. (1995). Kinerja dan Pengembangan Karyawan. Jakarta: Group Gramedia.

Rusli Syarif. (1991) Produktivitas, Angkasa Bandung,

Sen, A. (2000) Development as Freedom, Oxford University Press: New Delhi

Sripeni, R. (2008). Pemberdayaan Masyarakat Desa Melalui Pelatihan Keterampilan dan Kontribusinya Terhadap Kesejahteraan Keluarga, Jurnal Sosial, Vol. 9. No $2 . \quad$ Hal 46. http;//pdii.lpi.go.id/admin/31075466.pdf

Subagiyo, Ahmad Wito. (2000). Efektivitas Program Penanggulangan Kemiskinan dalam Pemberdayaan Masyarakat Perdesaan, Yogyakarta: UGM

Sudira, I Made. (2004). Evaluasi Program Penanggulangan Kemiskinan (Studi Kasus di Kecamatan Tabanan Kabupaten Tabanan), Tesis Program Pasca Sarjana Magister Ekonomi Pembangunan, Denpasar: Universitas Udayana.

Sugiarta, Eddy. (2007). Teori Kesejahteraan Sosial Ekonomi dan Pengukurannya. Jurnal Eksekutif. Vol. 4. No 2.

Simanjuntak, J Payaman. (1987). Pengukuran Produktivitas. Jakarta : Ghalia Indonesia

Soeharto, Edi. (2005). Membangun Masyarakat Memberdayakan Rakyat, PT. Refika Aditama, Bandung.

Sutrisno. (2009). Manajemen Keuangan Teori, Konsep dan Aplikasi.Yogyakarta: Ekonisia

Suud, Mohammad. (2006). 3 Orientasi Kesejahteraan Sosial. Jakarta: Prestasi Pustaka 
Swastha, Basu dan Ibnu Sukotjo. (1995). Pengantar Bisnis Modern Pengantar Ekonomi Perusahaan Modern. Liberty, Yogyakarta.

Takehara. (2005). http://library.binus.ac.id/eColls/eThesisdoc/Bab2/2010-2-00328-JP\%20bab \%202.pdf, diakses 5 Februar 2014)

Undang-Undang No 13 tahun 1998 tentang ketentuan pokok kesejahteraan masyarakat

Undang-Undang Republik Indonesia No.6 Tahun 1974 tentang ketentuan-ketentuan pokok kesejahteraan sosial pasal 2 ayat 1

Undang-undang no 13 tahun 1998 tentang-tentang ketentuan pokok kesejahteraan sosial

Undang-Undang Nomor 11 Tahun 2009 tentang Kesejahteraan Sosial

Wilensky, Harold L. (1965). "The Problems and Prospects of the Welfare State" dalam Industrial Society and Social Welfare. ed. Wilensky and Lebeaux. New York : The Free Press.

Woekirno Sumardi. (1979). Faktor-FaktorProduktivitas Karyawan. Jakarta: Gramedia.

Zikrullah, Y dan Adam. (2000). Struktur Ekonomi dan Pengentasan kemiskinan, Media Partisipatif - P2KP, No. 07 Edisi Oktober.

Zoe Oxaal. (1997). Education and Poverty: A Gender Analysis. Report Prepared for the Gender Equality Unit, Swedish International Development Coorporation Agency (Sida), Juni 1997 http://www.ids.ac.uk/bridge/ 